DOI: http://doi.org/10.31617/k.knute.2019-03-19.60

\title{
ІННОВАЦІЙНІ ТЕХНОЛОГІЇ В РЕКЛАМНІЙ ДІЯЛЬНОСТІ ПІДПРИЕМСТВА
}

\author{
Петрина М. Ю. \\ к.е.н., доцент \\ кафедра менеджменту та адміністрування \\ Винницький М. I. \\ студент \\ Інститут економіки та менеджменту \\ Івано-Франківський національний технічний університет \\ нафти і газу, Україна
}

Ключові слова: реклама, рекламна діяльність підприємства, інновацїі, інноваційні технологї̈.

Keywords: advertising, advertising activity of the enterprise, innovations, innovative technologies.

Поширення інноваційних технологій в сучасному нам світі зумовлюється різними чинниками: розвитком технологічної бази, становленням системи масових інтерактивних комунікацій, переосмисленням значимості інноваційності порівняно 3 ефективністю: коли діяльність, спрямована на збільшення репутаційного капіталу компанії реалізується у використанні засобів більшою мірою ефектних, ніж ефективних [1].

Рівень інноваційності в рекламі можна діагностувати за такими критеріями:

- використання професійного технічного забезпечення;

- використання новітніх комп'ютерних технологій;

- використання нестандартних способів подачі інформації, що виявляється в появі інноваційних рекламних форм.

Одним із прикладів інноваційної реклами $є 3 \mathrm{D}$, голографічна та мобільна реклама. Проте не всі підприємства можуть використовувати такі види реклами насамперед через брак необхідних коштів.

3D реклама - це один з останніх напрямів у сфері зовнішньої реклами, який за рахунок незвичайного об'ємного дизайну привертає увагу людей і допомагає просуванню продукції. Дослідження показують, що час спілкування 3 такою рекламою складає від 2 до 5 хвилин. 3D реклама не просто запам'ятовується, вона справляє враження. Люди фотографуються на іiі фоні, розповідають про побачене друзям. Всю 3D рекламу можна підрозділити в залежності від носія реклами: 
підлогова та настінна. 3D - реклама не тільки приверне увагу споживача, але й за допомогою об'ємного зображення грамотно представить товар.

Серед перспективних та якісно нових видів реклами, що активно використовується в галузі, $є$ відеореклама в місцях масового скупчення людей із застосуванням технології InDoor TV. Спеціалісти констатують високу ефективність такої реклами - вона концентрує увагу понад 90\% потенційних покупців. Удосконалення цієї технології призвело до появи на ринку InDoor реклами новітньої трьохвимірної технології X3D video, яка дозволяє картинці вільно виходити за межі екрана та повертатися назад. Серед переваг - реалістичне зображення на досить великих відстанях, яке, на відміну від простих 3D-технологій, не потребує для сприйняття трьохвимірного зображення використання додаткових засобів (спеціальних шоломів, стереоокулярів тощо). Водночас, застосування такої технології впливає на психологічне сприйняття реклами споживачем і справляє незабутнє враження на оточуючих та формує їхні позитивні емоції [2].

Не може залишитись непоміченим ще один нестандартний підхід у інформуванні споживача - технологія інтерактивної взаємодії JustTouch - завдяки великому сенсорному табло та легкому дотику, споживач може керувати функціями меню, та сам знайти потрібну йому інформацію щодо асортименту товару, його наявності, ознайомитися з програмою закладу, при цьому в поле його зору постійно потрапляє логотип рекламованого бренду. За допомогою такої системи будь-яка вітрина може перетворитися в повнофункціональний канал продажів [3].

Запропонована компанією GestureTek (США) технологія «Ground FX» являє собою проекцію об'ємного зображення на поверхню 3 можливістю його інтерактивної зміни, коли система зафіксує рух в навколишньому середовищі. «Жива картинка» викликає у споживача зацікавленість та позитивні емоції, що не може не позначатись на його ставленні до рекламованої продукції чи підприємства [2].

Особливе зацікавлення сьогодні викликає так званий «інтерактивний одяг». Такими, приміром, є інтерактивні відеофутболки. Сутність цієї інноваційної технології полягає в тому, що до тіла людини на спеціальний пояс кріпиться спеціальний екран, поверх якого вдягається звичайна однотонна футболка. Управління запрограмованим матеріалом здійснюється за допомогою контролера на поясі або ж дистанційного пульта, що дозволяє демонструвати рекламу синхронно. Якщо, наприклад, на шоу чи виставці задіяні навіть тисячі футболок - усі вони синхронно можуть керуватися з одного пульта. Це вигідно, коли оператор має близько десятка оплачених рекламних 
заказів рекламних компаній. Тоді він послідовно може вмикати на всіх футболках одночасно рекламу одного бренда, а потім змінювати iii на іншу. Або всі реклами підряд показують послідовно чи в хаотичному порядку [4].

Ще однією «новинкою» стала японська технологія Free Format Projection. Вона створює відчуття присутності персонажів або інших об'єктів у натуральну величину за рахунок особливої обробки зображення, яке згодом проектується на поверхню. При використанні даної технології фантазія рекламодавця може бути безмежна: величезна пляшка, що танцює біля входу в розважальний центр, консервна банка, прогулюються між рядами в супермаркеті і т. д.

Цікавою також є технологія туман-екран (Walkthru Fog Screen). Це пристрій, що створює за допомогою ультразвукових хвиль 3 найменших крапель води пласку поверхню для демонстрації відеороликів чи зображень. Особливістю такого екрана $\epsilon$ те, що глядач може пройти крізь інсталяцію, не пошкодивши іiі. Відео демонструють за допомогою звичайного проектора.

Останнім часом поширення набуває також мобільна реклама. Це - інформування споживачів про продукт чи послугу та заохочення до їх покупки через мобільний телефон. Мобільна реклама є частиною ширшого поняття - мобільний маркетинг. Мобільна реклама на сьогодні - це здебільшого графічні банери та посилання на сайтах в мобільному Інтернеті. Такі сайти переглядаються 3 мобільного телефону (також відомі як WAP-сайти). Натиснувши на посилання абонент переходить на мобільний сайт рекламодавця, де читає інформацію про продукт чи послугу. Використання Інтернету як каналу розповсюдження інформації вигідне 3 економічної точки зору, оскільки охоплення однієї тисячі осіб за допомогою Інтернету коштує в 50 разів дешевше ніж за допомогою телебачення.

Уся проаналізована інноваційна реклама виконує велику кількість функцій, головною з яких $\epsilon$, передусім, привернути увагу до самої себе. Адже така реклама незвична. Вона вражає, а отже не може залишитися поза увагою аудиторії. Інноваційна реклама допомагає вигідно виділити пропонований товар та його продавця, інформуючи про товар або послугу, певним чином позиціонує продукцію компанії.

\section{Список використаних джерел}

1. Глушкова Т. В. Інноваційні складники сучасної реклами / Т. В. Глушкова // Актуальні питання масової комунікаці. - 2013. Випуск 14. - С. 140-143. 
2. Струніна Л. В. Впровадження інноваційних технологій в рекламну діяльність [Електронний ресурс]. - URL : http: // dspace.nuft.edu.ua / jspui / bitstream / 123456789 / 4377 / 1 / Strunina_ Innovative_ technology_in_advertisement.pdf

3. Школа рекламіста [Електронний ресурс]. - http://www.advertiserschool.ru/ від 10.04.2011 p.

4. Интерактивные футболки. Представительство Центра Маркетинга США в Украине и СНГ [Електронний ресурс]. - URL : http://www. best-promoitems.com/ rus/interactive-futbolka.php

DOI: http://doi.org/10.31617/k.knute.2019-03-19.61

\title{
ПСИХОЛОГІЧНІ ВІЙНИ - ВІЙНИ ХХІ СТОЛІТТЯ
}

\author{
Проха А. C. \\ студентка 3 курсу \\ кафедра маркетингу \\ Гамова I. B. \\ к.е.н., доцент \\ кафедра журналістики та реклами \\ Київський національний торговельно-економічний університет, \\ Україна
}

Ключові слова: психологічна війна,, холодна війна, інформачійний вплив, саботаж, пропаганда.

Keywords: psychological warfare, cold war, information influence, sabotage propaganda.

Факти здійснення інформаційного впливу на широку аудиторію можна виявити протягом усієї історії суспільства. Зрозуміло, що в різні періоди інтенсивність застосування тих чи інших способів впливу, як і рівень його організації, змінювалися.

Люди живуть в інформаційному полі і щодня черпають інформацію з преси, радіопередач, з екранів телевізорів. Знаходячись часто в світі відірваних від реальності символів, вони можуть йти навіть проти своїх власних інтересів. Реальність може відходити на другий план, грати підлеглу роль. В цьому значенні людина не є вільною, тим більше що відпрацьований ряд способів ефективної інформаційної дії.

Сучасні можливості електронних 3МI, поліграфії, розмножувальної й іншої техніки в поєднанні з науковою та публіцистичною літературою, періодикою дозволяють ефективно впливати на розум, 